\title{
PARTISIPASI URANG BANJAR DALAM KEBERHASILAN PEMILU DI KALIMANTAN SELATAN
}

\author{
Muhammad Risalan Uzhma \\ Email: 2010128110004@mhs.ulm.ac.id \\ Program Studi Pendidikan IPS Fakultas Keguruan dan Ilmu Pendidikan \\ Universitas Lambung Mangkurat \\ Banjarmasin
}

\begin{abstract}
Abstrak
Pemilu merupakan singkatan dari pemilihan umum. Pemilihan umum adalah bentuk pengaplikasian dari kedaulatan rakyat dalam memilih dan menggunakan hak suaranya sebagai partisipasi kepada negara. Dilihat dari pandangan HAM, pemilu adalah pelaksanaan hak dari individu yang menjadi dasar serta masa depan dari proses bernegara. Indonesia telah melaksanakan pemilu yang dalam lingkup nasional dalam 12 kali yaitu tahun 1955, 1971, 1977, 1982, 1987, 1992, 1997, 1999, 2004, 2009, 2014, dan 2019. Keberhasilan dari suatu pemilu dapat dilihat dari seberapa besar partisipasi politik dalam hal ini pemilu yang berlangsung. Partisipasi urang Banjar atau masyarakat Kalimantan Selatan dalam pemilu kepala daerah pada tahun 2015 dan 2020 mengalami kenaikan yang dapat diartikan bahwa kesadaran akan pemilu sudah mulai berkembang dimasyarakat.
\end{abstract}

\section{PENDAHULUAN}

Pemilu merupakan singkatan dari pemilihan umum. Pemilihan umum adalah bentuk pengaplikasian dari kedaulatan rakyat dalam memilih dan menggunakan hak suaranya sebagai partisipasi kepada negara (Wardhani, 2018: 58). Dalam pemilu, seseorang berhak untuk memilih dan menentukan calon yang akan dipilih tanpa adanya paksaan dari pihak tertentu. Pemilu dilaksanakan dengan keterbukaan dan kebebasan sebagai bukti partisipasi dari rakyat untuk menggunakan haknya untuk memilih. 
(Budiarjo, 2007: 461). Pemilu ini terjadi di berbagai negara untuk memilih atau menyuarakan haknya dalam pemilihan perwakilan rakyat. Pemilu juga terjadi di Indonesia, terutama untuk pemilihan eksekutif dan legislatif.

Pemilu juga dapat digunakan sebagai sarana untuk pemilihan suatu kepala daerah, rakyat memiliki haknya untuk menentukan calon pemimpin atau kepala daerah ditempat tersebut. Hasil dari pemilu ini nantinya akan berdampak terhadap daerah tersebut, dampak tersebut berupa kearah yang baik atau buruk. Dalam pelaksanaannya, pemilu ini ada orang yang mengikuti dan juga ada yang tidak mengikuti pemilu. Orang yang mengikuti pemilu adalah orang yang turut serta untuk membangun negara maupun daerah. Sedangkan orang yang tidak mengikuti pemilu atau menggunakan hak suaranya maka orang tersebut tidak ikut berpartisipasi untuk kemajuan negara maupun daerah.

Pada urang Banjar lebih tepatnya di Kalimantan selatan, proses pemilu dilaksanakan sebagaimana juga yang dilakukan di daerah-daerah di Indonesia. Urang Banjar memiliki hak untuk memilih dan juga menentukan orang yang ingin dipilihnya baik sebagai kepala daerah maupun perwakilan untuk daerah Kalimantan Selatan yang tentun untuk kemajuan dan perkembagan Kalimantan Selatan. Suara yang mereka berikan dari urang Banjar tentunya akan sangat berpengaruh terhadap jalannya pemerintahan di Kalimantan Selatan.

\section{METODE PENELITIAN}

Metode yang digunakan adalah metode studi pustaka dengan menelaah serta memahami dari buku-buku, dokumen, atau sumber ilmiah lainnya yang didapatkan dari media tidak cetak yang relevan serta mendukung dalam penulisan publikasi dari Partisipasi Urang Banjar Dalam Keberhasilan Pemilu Di Kalimantan Selatan.

\section{KONSEP PEMILU DI INDONESIA}

Pemilu adalah sebuah kegiatan yang dilakukan oleh seseorang dengan menggunakan hak suaranya untuk memilih calon yang tersedia yang menurut mereka 
terbaik. Pemilu adalah salah satu cara untuk memilih pemimpin atau yang ada dipemerintahan dari persetujuan yang didapatkan dari suara rakyat yang memilihnya. Menurut Dahl dalam Lesmana (2019: 2), pemilu secara umum adalah praktek politik pada sebuah pemerintahan yang kemungkinan terbentuknya wakil dari rakyat untuk pemerintahan.

Dilihat dari pandangan HAM, pemilu adalah pelaksanaan hak dari individu yang menjadi dasar serta masa depan dari proses bernegara. Indonesia telah melaksanakan pemilu yang dalam lingkup nasional dalam 12 kali yaitu tahun 1955, 1971, 1977, 1982, 1987, 1992, 1997, 1999, 2004, 2009, 2014, dan 2019 (Supriyadi, 2018: 1). Tahun 1955 adalah pemilu yang dilaksanakan pada saat orde lama. Pada saat itu pemilu dilaksanakan dengan dua sesi, sesi pertama untuk pemilihan anggota DPR dan sesi kedua untuk memilih anggota konstituante dengan suasana yang khidmat, tidak adanya batasan partai politik yang boleh mengikuti pemilu, dan pemerintah tidak melakukan intervensi terhdap partai-partai yang ikut serta dalam pemilu, hal tersebut karena merupakan pemilu pertama yang dilakukan dalam keadaan setelah kemerdekaan 1945.

Pemilu tahun 1971 yang merupakan pemilu kedua yang terjadi pasca kemerdekaan. Pemilu tersebut berbeda dengan pemilu sebelumnya yang mana partai pada pemilu kali ini dibatasi hanya 10 partai politik yang mengikuti pemilu yaitu PNI, Masyumi, NU, PKI, Partai Katolik, Partindo, Partai Murba, PSII Arudji, IPKI, dan Partai Islam Perti yang ikut serta dalam pemilu tahun 1971 dengan perbandingan yang terpilih dengan penduduk adalah 1:400.000 yang artinya tiap satu wakil di pemerintahan mewakili 400.000 penduduk di Indonesia (Budiarjo, 2007: 474-476). Kemudian pada tahun 1973, presiden Soeharto menyederhanakan partai politik yang sebelumnya berjumlah 10 menjadi 3 golongan yaitu golongan spiritual, nasionalis, dan golongan karya yang kemudian berlanjut kepada pemilu ketiga pada tahun 1977 dengan partisipasi ketiga golongan tersebut dengan partainya Golkar, PPP, dan PDI. Pada saat itu muncul golongan putih (Golput) yang tidak menggunakan hak suaranya dalam pemilu tahun 1977, hal tersebut karena menurut mereka pemilu tahun 1977 kurang memenuhi syarat yang dibutuhkan dalam pelaksanaan pemilu secara demokratis. Untuk pemilu yang dilaksanakan pada 1982-1997 memiliki kemiripan dengan pemilu sebelumnya yang pada akhirnya Soerharto mengundurkan diri dari jabatan presidennya. 
Pemilihan umum dalam masa reformasi berlangsung pada tahun 1999 sampai yang telah dilaksanakan pada tahun 2019. Pada masa reformasi, pemilu tahun 1999 diikuti oleh tiga partai orde baru yang ditambahkan dengan partai baru sehingga berjumlah 48 partai dengan landasan hukumnya berdasarkan UU No. 2 Tahun 1999. Pada tahun 2004 dilaksanakan pemilu untuk memilih anggota legislatif seperti DPR, ekskutif seperti presiden putaran pertama dan kedua. Untuk partai yang mengikuti pemilu legislatif berjumlah 24 partai yang perwakilannya masuk ke DPR berjumlah 7 partai. Pemilu eksekutif dilaksanakan dengan dua putaran karena tidak terpenuhinya perolehan suara 50\% plus satu maka pemilu dilaksanakan dengan dua putaran. Pemilu 2009 seperti halnya pemilu tahun 2004 juga dilaksanakan pemilu untuk legislatif dan eksekutif dengan hanya satu putaran karena memenuhi persyaratan, akan tetapi terdapat permasalahan yang terjadi karena ketidaksiapan dari pihak panitia pemilu atau KPU tentang pemilih tetap, pada saat itu diikuti oleh 12 partai. Pemilu tahun 2014 addalah pemilihan yang dilakukan untuk memilih eksekutif dengan hanya satu putaran juga dan legislatif dengan tingkat partisipasi lebih banyak dibandingkan dengan pemilu tahun 2009. Pemilu 2019, pemilu yang seperti halnya sebelumnya untuk memilih legislatif dan eksekutif dengan hanya satu putaran dengan diikuti 14 partai politik.

Dari masa ke masa pemilu yang dilakukan dengan berbagai macam perubahan yang juga dilakukan, hal tersebut tentunya memiliki tujuan untuk kemajuan dari negara Indonesia juga, karena dari hasil pemilu yang merupakan aspirasi dan suara dari rakyat yang digunakan dalam pemilu yang nantinya akan berdampak terhadap jalannya pemerintahan yang akan dijalani. Pada pelaksanaan pemilu harus dilaksanakan secara langsung, umum, bebas, jujur dan adil sebagaimana yang tercantum dalam pasal $22 \mathrm{E}$ Undang-Undang Dasar 1945 mengenai pemilihan umum. Akan tetapi sering dijumpai pelaksanaan pemilu kecurangan yang dilakukan oleh adanya pihak tertentu yang ingin pihak mereka untuk menjadi pemenang dalam penyelenggaraan pemilihan umum.

Dalam sebuah pemilu, tidak akan terlepas dengan panitia atau badan yang mengelola tentang pemilu yaitu KPU dan BAWASLU yang merupakan dua lembaga yang berkaitan dengan pemilu yang memiliki kewenangan dalam penyelenggaraan pemilu yang berdasarkan kode etik dalam pemilu (Ridwan, Sardini, \& Adnan: 2). Kode etik sangat diperlukan dalam sebuah pemilu, karena sebagai pedoman mengenai apa 
saja yang harus dilakukan dan hal yang harus dihindarkan sebagai sebuah norma yang berlaku dalam sebuah pemilu. Pemilu tanpa adanya kode etik akan menjadi pemilu yang tidak teratur dan bahkan dapat terjadinya pelanggaran pada pemilu. Namun dalam kenyataannya masih ada pelanggaran dalam pemilu yang dilakukan oleh berbagai pihak. Adanya pihak tertentu yang memanfaatkan partisipan dalam pemilu untuk melakukan kecurangan seperti halnya menyogok orang yang nantinya akan menggunakan hak suaranya yang dipengaruhinya untuk memilih calon tertentu.

Keberhasilan dari pemilu tidak hanya dapat dilihat dari pelaksanaan pemilu tersebut dalam hal kelengkapan pemilu sampai ke keamanan dalam pemilu, namun juga adanya partisipasi dari masyarakat dalam pemilu yang nantinya juga dapat mempengaruhi keberhasilan dari pemilu. Partisipan pemilu yang menggunakan hak suaranya berdasarkan kehendaknya sendiri dan menurut mereka yang dipilih tersebut adalah yang terbaik maka akan berdampak nantinya terhadap jalannya pemerintahan dan sebagainya. Semakin banyak para pemilih yang menggunakan hak suaranya maka keberhasilan pemilu akan semakin tinggi.

\section{PARTISIPASI URANG BANJAR DALAM PEMILU}

Pemilu di kalimantan selatan yang mana peserta pemilunya berasal dari penduduk kalimantan selatan atau urang banjar dalam kriteria tertentu. Keberhasilan dari suatu pemilu dapat dilihat dari seberapa besar partisipasi politik dalam hal ini pemilu yang berlangsung. Partisipasi yang dapat dilakukan adalah dengan mencalonkan diri dalam pemilu, kampanye dari pasangan calon yang nantinya maju dalam pemilu dan mengikuti proses pemilu sebagaimana aturan yang telah ditetapkan. Seseorang berhak untuk memilih atau menggunakan hak suaranya dengan kriteria atau syarat yaitu warga negara Indonesia, berumur 17 tahun, terdaftar sebagai calon pemilih tetap, tidak ada gangguan jiwa, dan tidak dicabut hak untuk memilihnya karena berbagai sebab.

Pemilu di Kalimantan Selatan seperti halnya pemilihan umum dengan didaerah lainnya, yang didasari dari adanya kode etik dalam pemilu sebagai pedoman dalam pelaksanaan pemilu yang dilakukan di kalimantan selatan oleh urang Banjar. Partisipasi urang Banjar atau masyarakat Kalimantan Selatan dalam pemilu kepala daerah pada 
tahun 2015 mencapai angka 1.906.249 partisipan dari 2.840.520 pengguna hak pilih (https://pilkada2015.kpu.go.id/kalselprov) Sedangkan pada tahun 2020, partisipasi dalam pemilu mencapai angka 1.695 .517 partisipan yang mengikuti pemilu dari 2.793.811 dari pengguna hak pilih (https://pilkada2020.kpu.go.id). Dari data tersebut menunjukan bahwa terjadi kenaikan partisipasi pemilu yang dilakukan oleh urang Banjar yaitu 164.023 partisipan yang mengikuti pemilu kepala daerah di Kalimantan Selatan.

Kesadaran masyarakat akan pentingnya pemilu yang akan berdampak terhadap pemerintahan terutama di Kalimantan Selatan selama 2 periode pemilu yaitu 2015 dan 2020 mengalami kenaikan, yang dapat diartikan bahwa kesadaran akan pemilu sudah mulai berkembang dimasyarakat. Mereka yang menggunakan hak suaranya dalam pemilu secara tidak langsung juga berpartisipasi dalam bentuk menyampaikan suara melalui pemilu yang dilaksanakan di Kalimantan Selatan. Tidak hanya disaat proses pemilihan umum di Kalimantan Selatan saja yang menjadi ukuran dalam keberhasilan pemilu dari partisipan yang ikut serta, namun juga disaat sebelum proses pemilu berlangsung seperti halnya pencalonan, adanya calon yang akan dipilih dalam pemilu di Kalimantan Selatan menjadi sebuah syarat pemilu dapat terlaksana. Kemudian, adanya kampanye setelah proses pencalonan, yang dilakukan oleh para pasangan calon untuk mendapatkan suara dari masyarakat pada pemilihan umum yang dilaksanakan. Ketiga hal tersebut menjadi salah satu hal yang menjadi ukuran dari keberhasilan pemilu yang tidak hanya di Kalimantan Selatan, namun juga daerah-daerah lain khususnya di Indonesia.

\section{SIMPULAN}

Pemilihan umum adalah bentuk pengaplikasian dari kedaulatan rakyat dalam memilih dan menggunakan hak suaranya sebagai partisipasi kepada negara. Pemilu dilaksanakan dengan keterbukaan dan kebebasan sebagai bukti partisipasi dari rakyat untuk menggunakan haknya untuk memilih. Pemilu juga dapat digunakan sebagai sarana untuk pemilihan suatu kepala daerah, rakyat memiliki haknya untuk menentukan calon pemimpin atau kepala daerah ditempat tersebut. Hasil dari pemilu ini nantinya 
akan berdampak terhadap daerah tersebut, dampak tersebut berupa kearah yang baik atau buruk. Urang Banjar memiliki hak untuk memilih dan juga menentukan orang yang ingin dipilihnya baik sebagai kepala daerah maupun perwakilan untuk daerah Kalimantan Selatan yang tentun untuk kemajuan dan perkembagan Kalimantan Selatan. Suara yang mereka berikan dari urang Banjar tentunya akan sangat berpengaruh terhadap jalannya pemerintahan di Kalimantan Selatan.

Pemilu adalah sebuah kegiatan yang dilakukan oleh seseorang dengan menggunakan hak suaranya untuk memilih calon yang tersedia yang menurut mereka terbaik. Menurut Dahl), pemilu secara umum adalah praktek politik yang dilaksanakan pada sebuah pemerintahan yang kemungkinan terbentuknya wakil dari rakyat untuk pemerintahan. Dilihat dari pandangan HAM, pemilu adalah pelaksanaan hak dari individu yang menjadi dasar serta masa depan dalam kehidupan bermasyarakat dan bernegara. Indonesia telah melaksanakan pemilu yang dalam lingkup nasional dalam 12 kali yaitu tahun 1955, 1971, 1977, 1982, 1987, 1992, 1997, 1999, 2004, 2009, 2014, dan 2019. Dalam sebuah pemilu, tidak akan terlepas dengan panitia atau badan yang mengelola tentang pemilu yaitu KPU dan BAWASLU yang merupakan dua lembaga yang berkaitan dengan pemilu yang memiliki kewenangan dalam penyelenggaraan pemilu yang berdasarkan kode etik dalam pemilu. Keberhasilan dari pemilu tidak hanya dapat dilihat dari pelaksanaan pemilu tersebut dalam hal kelengkapan pemilu sampai ke keamanan dalam pemilu, namun juga adanya partisipasi dari masyarakat dalam pemilu yang nantinya juga dapat mempengaruhi keberhasilan dari pemilu.

Pemilu di kalimantan selatan yang mana peserta pemilunya berasal dari penduduk kalimantan selatan atau urang banjar dalam kriteria tertentu. Seseorang berhak untuk memilih atau menggunakan hak suaranya dengan kriteria atau syarat yaitu warga negara Indonesia, berumur 17 tahun, terdaftar sebagai calon pemilih tetap, tidak ada gangguan jiwa, dan tidak dicabut hak untuk memilihnya karena berbagai sebab. Kesadaran masyarakat akan pentingnya pemilu yang akan berdampak terhadap pemerintahan terutama di Kalimantan Selatan selama 2 periode pemilu yaitu 2015 dan 2020 mengalami kenaikan, yang dapat diartikan bahwa kesadaran akan pemilu sudah mulai berkembang dimasyarakat. Tidak hanya disaat proses pemilihan umum di Kalimantan Selatan saja yang menjadi ukuran dalam keberhasilan pemilu dari partisipan yang ikut 
serta, namun juga disaat sebelum proses pemilu berlangsung seperti halnya pencalonan, adanya kampanye setelah proses pencalonan sebagai bentuk partisipasi pemilu yang ada di Kalimantan Selatan.

\section{REFERENSI}

Akhmad, B. A., \& Sarwani, I. U. A. M. (2021, April). PELAYANAN KOMUNIKASI PEMERINTAHAN PEMERINTAH DAERAH KEPADA STAKEHOLDERNYA (STUDI PADA PEMERINTAH PROVINSI KALIMANTAN SELATAN). In PROSIDING SEMINAR NASIONAL LINGKUNGAN LAHAN BASAH (Vol. 6, No. 3).

Anis, M. Z. A., \& Wiyanarti, E. HISTORICAL LEARNING THROUGH THE HISTORICAL THINKING LEARNING MODEL (MPBH) BASED ON ISSUE CENTERED HISTORY BRINGS STUDENTS CAN THINK CRITICAL THINKING REALITY AND EXPECTATIONS. Jurnal Socius, 10(1), 1-11.

Annisa, M. (2020). Upaya Komisi Pemilihan Umum Kabupaten Tanah Laut Dalam Meningkatkan Partisipasi Pemilih Pada Pemilihan Umum Tahun 2019. Perpustakaan UIN Antasari Banjarmasin.

Budiarjo, M. (2007). Dasar-Dasar Ilmu Politik. PT Gramedia Pustaka Utama.

Jamaluddin, J., Syaharuddin, S., \& Putra, M. A. H. (2020). The Form of Basirih Society Social Interaction in The Dome of Habib Hamid Bin Abbas Al-Bahasyim as a Learning Resource on Social Studies. The Kalimantan Social Studies Journal, 1(2), 159-168.

Komisi Pemilihan Umum. "Penetapan Rekapitukasi Pemilihan Gubernur dan Wakil Gubernur Kalimantan Selatan.” pilkada2020.kpu.go.id. https://pilkada2020.kpu.go.id/\#/ppkwp/penetapan/63 (Diakses Mei 21, 2021).

Komisi Pemilihan Umum. "Pilkada Provinsi Kalimantan Selatan." pilkada2015.kpu.go.id. https://pilkada2015.kpu.go.id/kalselprov (Diakses Mei 21, 2021). 
Kurniawati, M., \& Wardani, F. (2020). Pendampingan Perempuan dalam Mendidik Keluarga untuk Menyikapi Informasi Berita Hoax Menjelang Pemilu 2019 di Kabupaten Barito Kuala Kalimantan Selatan. Journal of Servite, 1(2), 10-19.

Lesmana, B. (2019). Penerapan Aspek Rasionalitas Dalam Pemilu 2019 (Studi Terhadap Tingkat Partisipasi Politik ODGJ di Kabupaten Hulu Sungai Utara). Al'iidara Balad, 1(1), 1-43.

Maghpirah, M. (2021). PARTISIPASI POLITIK PENYANDANG DISABILITAS PADA PEMILU SERENTAK TAHUN 2019 (Studi Kasus di Kota Banjarmasin). Perpustakaan UIN Antasari Banjarmasin.

Pahlevi, I. (2016). EVALUASI PENYELENGGARAAN PEMILIHAN UMUM ANGGOTA LEGISLATIF 2014: STUDI DI PROVINSI KALIMANTAN SELATAN DAN BANGKA BELITUNG. Kajian, 20(2), 87-108.

Purnomo, P., Putro, H. P. N., \& Anis, M. Z. A. (2018). Cooperation of Transmigration Community with Local Communities in Alur Village, Tanah Laut Regency. TROPICAL WETLAND JOURNAL, 4(2), 34-27.

Putro, H. P. N., Arisanty, D., \& Anis, M. Z. A. (2020, August). Learning Model of History to Wetlands for Historical Consciousness. In International Conference On Social Studies, Globalisation And Technology (ICSSGT 2019) (pp. 67-74). Atlantis Press.

Ridwan, J. F., Sardini, N. H., \& Adnan, M. (2017). Peranan Dewan Kehormatan Penyelenggara Pemilu (DKPP) Dalam Menegakkan Kemandirian, Integritas, dan Kredibilitas Penyelenggara Pemilu Dalam Pemilu Kepala Daerah dan Wakil Kepala Daerah Tahun 2015. Journal of Politic and Government Studies, 6(04), 331-340.

Supriyadi, P. (2018). SEJARAH PEMILU DEMOKRATIS DI INDONESIA TAHUN 1999-2014 (Doctoral dissertation, Universitas Pendidikan Indonesia). 
SYAUFI, A. (2020). PENERAPAN SANKSI PIDANA BAGI PELAKU TINDAK PIDANA PEMILU PADA PEMILU LEGISLATIF TAHUN 2019 DI PROVINSI KALIMANTAN SELATAN. Eprints ULM.

Wardhani, P. S. N. (2018). Partisipasi Politik Pemilih Pemula dalam Pemilihan Umum. JUPIIS: Jurnal Pendidikan Ilmu-Ilmu Sosial, 10(1), 57-62. 